\title{
NUTRITIVE ADEQUACY AND CLINICAL TOLERANCE OF MODIFIED HUMAN GLOBIN ${ }^{1}$
}

\author{
By GEORGE J. GABUZDA, Jr.,2 GERALD B. PHILLIPS, AND \\ CHARLES S. DAVIDSON \\ (From the Thorndike Memorial Laboratory, Second and Fourth Medical Services [Harvard], \\ Boston City Hospital, and the Department of Medicine, \\ Harvard Medical School, Boston, Mass.)
}

(Submitted for publication Oct. 27, 1952; accepted May 22, 1953)

The production of plasma and its fractions from whole blood has led to investigations of the usefulness of the red cell residues. Globin, the protein moiety of hemoglobin, can be obtained in quantity from the red blood cells remaining after the plasma has been removed. Modification ${ }^{3}$ (1) of this protein renders it suitable for intravenous use. Previous studies suggest that this material may have osmotic properties useful in treating shock and may be a source of protein for parenteral administration (2-7). The present investigation was designed to elucidate further the usefulness of modified human globin with particular regard to its nutritive value and clinical tolerance in man.

\section{MATERIALS AND METHODS}

Clinical tolerance to intravenous infusions of modified human globin was observed in 20 convalescent patients, and the nutritive value of this protein was investigated by nitrogen balance studies in six male subjects. Four of these six subjects, M. M. age $50, J$. R. age $35, F$. O'D. age 60 , and $W$. O. age 43 , were essentially normal except for a moderate degree of undernutrition; one, J. B. age 43, had minimal cirrhosis of the liver proven by biopsy; and one, J. G. age 28, was a normal medical student. None of the patients, except J. B., had evidence of liver or renal disease. They were maintained on the Thorndike metabolic ward and offered diets providing constant intakes of protein and calories. Dietary nitrogen and calorie intakes were calculated from standard food tables $(8,9)$. Macro-Kjeldahl analysis of three separate lots of modified human globin yielded an average value for nitrogen content of 15.7 per cent. In these studies the conventional factor 6.25 was used to convert globin protein to nitrogen. The nitrogen content of the isoleucine

1 The expenses of this study were defrayed in part by a grant from Sharp \& Dohme, Inc., West Point, Pennsylvania to Harvard University.

2 Welch Fellow in Internal Medicine of the National Research Council.

8 "Modified human globin" was furnished for this study by Dr. William Boger, Sharp \& Dohme, Inc., Glenolden, Pennsylvania. used was calculated from the analytical data provided by the manufacturer. Analyses of the diets for nitrogen content were not done. In the case of the diets which were essentially devoid of protein, the errors introduced by the use of calculated values rather than analyzed values for nitrogen intake would be minimal. In the case of those subjects given diets containing moderate amounts of protein the nitrogen intake error might be greater, but since the subjects studied were maintained on constant diets before, during, and after globin administration this intake error would be constant and would not invalidate the observations concerned with the metabolism of globin. This intake error would however, detract from the precision of those studies designed to compare the nutritive adequacy of globin with that of dietary protein.

The patients were weighed daily under constant conditions. The 24-hour urine volumes were collected in $10 \mathrm{cc}$. of a 5:1 mixture of glacial acetic acid and toluol as preservative. Daily urinary nitrogen determinations were done by standard micro-Kjeldahl analysis. Urinary protein nitrogen was considered as the difference between total nitrogen and non-protein nitrogen after the removal of urine protein by precipitation with Folin-Wu reagent. Pooled stools, obtained during each control and experimental study period, were preserved with benzoic acid and refrigeration. The stool nitrogen content was determined by the macro-Kjeldahl technique.

The preparation of the modified human globin used in these investigations followed the method developed by Strumia and Sample (1) with suitable modifications instituted by the manufacturer (10). In the following studies globin was prepared for use as a 4 per cent solution in distilled water. This aqueous solution of globin produced hemolysis in vitro, so that now glucose or saline diluent is preferred.

Serum globin concentration was determined by the method of Kendall and Abell as described by Sample, Strumia, and Satta (11) and plasma and urine alpha amino nitrogen by that of Hamilton and Van Slyke (12).

\section{RESULTS}

I. Nutritive adequacy. Observations were made on the nutritive adequacy and the metabolism of modified human globin administered to six adult men. 


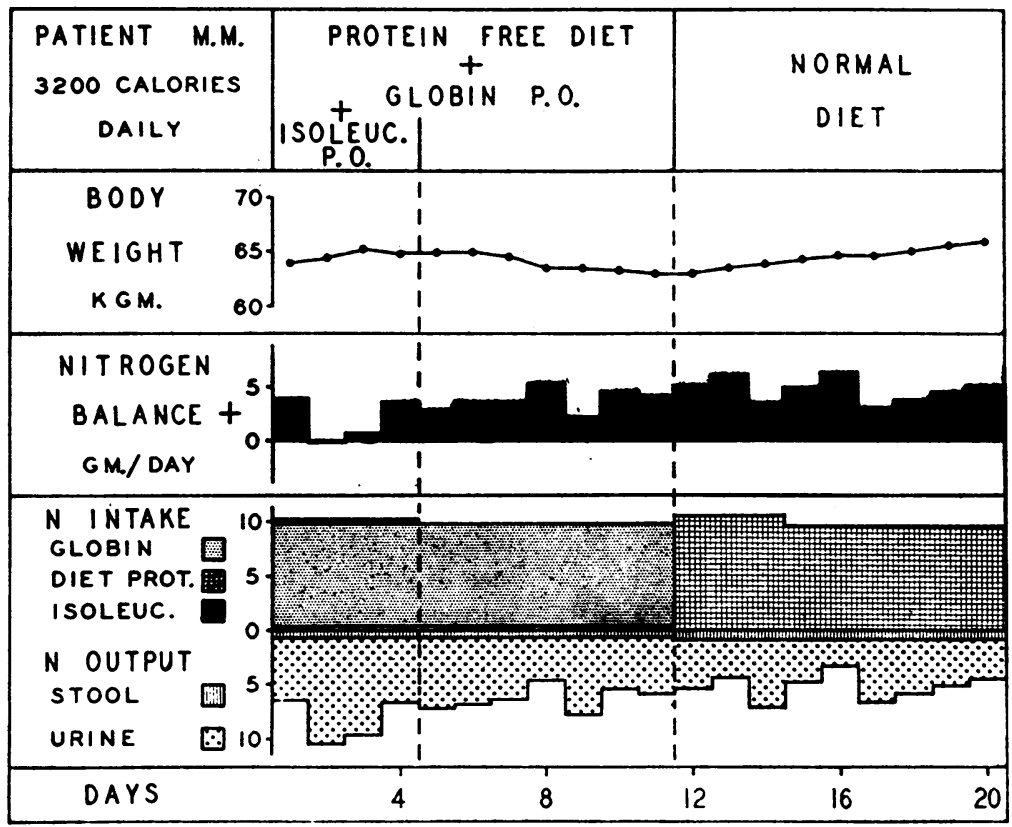

Fig. 1. Modified Human Globin Administered Orally as a Sole Source of Protein with and without Isoleucine

The nutritive adequacy of a protein is dependent in part upon its content of essential amino acids. Isoleucine is the essential amino acid present in globin in smallest concentration (Table I). The initial metabolic studies were designed to de-

TABLE I

Analysis of modified human globin for content of "essential" amino acids

\begin{tabular}{lcc}
\hline \hline & $\begin{array}{c}\text { Analysis } \\
\text { of } \\
\text { globin* } \\
G m . / 100 \mathrm{Gm} .\end{array}$ & $\begin{array}{c}\text { "Minimum } \\
\text { daily } \\
\text { requirement" } \\
(\mathbf{1 3 )}\end{array}$ \\
\hline Methionine & 1.0 & 1.10 \\
Tryptophan & 1.5 & 0.25 \\
Isoleucine & 0.3 & 0.70 \\
Leucine & 12.9 & 1.10 \\
Valine & 9.2 & 0.80 \\
Histidine & 5.6 & $\dagger$ \\
Arginine & 2.9 & $\dagger$ \\
Threonine & 3.5 & 0.50 \\
Phenylalanine & 5.7 & 1.10 \\
Lysine & 8.5 & 0.80 \\
\hline
\end{tabular}

* The amino acids indicated, excepting tryptophan, were determined by microbiologic assay (14) of lot number 38-2 of modified human globin following acid hydrolysis. Tryptophan was determined microbiologically following alkaline hydrolysis of the globin. The manufacturer's analysis of other lots of globin indicate an isoleucine content of 0.6 per cent and Albanese reported human hemoglobin to contain 0.5 per cent of this amino acid (15).

$\dagger$ Not required for maintenance of nitrogen equilibrium in adult man (13). termine whether or not the low concentration of this amino acid limited the ability of globin to maintain nitrogen balance in adult man. Patient M. M. (Figure 1) was maintained on a constant diet providing 3,200 calories daily. This diet was essentially devoid of protein, and contained only $0.3 \mathrm{Gm}$. of nitrogen per day by macro-Kjeldahl analysis. ${ }^{4}$ In addition to the basal diet, the patient received a multiple vitamin capsule daily. ${ }^{5}$ During the first four days of study this patient ingested as a sole source of protein an amount of globin furnishing $9.6 \mathrm{Gm}$. of nitrogen daily. In addition, he received $1 \mathrm{Gm}$. dl-isoleucine ${ }^{6}$ orally three times daily. During these four days nitrogen balance and body weight were maintained. On the fifth day isoleucine administration was stopped, but the globin was continued for the next seven

\& This diet maintained nitrogen balance and body weight in a normal male when casein was provided as the sole source of dietary protein.

s "Dayamin," furnished by Abbott Laboratories, North Chicago, Illinois, and containing per capsule: thiamine hydrochloride $5 \mathrm{mg}$., riboflavin $5 \mathrm{mg}$., ascorbic acid 100 mg., nicotinamide $25 \mathrm{mg}$., pantothenic acid $5 \mathrm{mg}$., pyridoxine $1.5 \mathrm{mg}$., vitamin A 10,000 U.S.P. units, and vitamin D 1,000 U.S.P. units.

6 Provided by Merck and Company, Rahway, New Jersey. 
days. Were isoleucine a limiting amino acid, an immediate negative nitrogen balance with increase in the output of urinary nitrogen would be expected. This did not occur. In fact, the nitrogen balance and body weight during the period in which globin was administered alone by mouth was comparable to the previous period in which isoleucine was given in addition to globin. During the ensuing nine days of study the patient was given food protein containing nitrogen approximately equivalent to that in the previously administered globin. There was essentially no change in nitrogen balance. A second normal individual (J. G., Figure 2) studied in a similar manner yielded comparable results.

A third patient (J. B., Figure 3) was provided with a similar protein-free basal diet and given globin equivalent to $7.1 \mathrm{Gm}$. of nitrogen intravenously daily as the sole source of protein for five days. $\mathrm{Ni}$ trogen balance and body weight were maintained. The trend toward less positive nitrogen balance during the last two days of this period of study was due to an increase in the urinary excretion of protein. Earlier in his study, J. B. was given globin intravenously in addition to a $50 \mathrm{Gm}$. protein diet. During the period of globin ad- ministration nitrogen balance was more positive than during the initial control period, indicating retention of globin nitrogen.

F. O'D. (Figure 4) illustrates another metabolic study in which globin was administered intravenously as a supplement to a diet. During the initial six day control period, the patient was maintained on a constant diet providing $35 \mathrm{Gm}$. of protein and 3,000 calories daily. Globin providing $4.8 \mathrm{Gm}$. of nitrogen was added intravenously daily during the next six days. This regimen was followed by a second six-day control period. During the period of intravenous globin administration, a more positive nitrogen balance was obtained than during either the fore- or after-control period. Urine nitrogen excretion increased significantly during globin administration, but was largely attributable to protein (presumably globin) in the urine. In the control period following intravenous globin administration there was an increased output of urinary non-protein nitrogen and a slight negative nitrogen balance suggesting metabolism of the previously administered protein. During the last nine-day period of study this patient was given a quantity of dietary protein equivalent in terms of nitrogen content to the globin previously

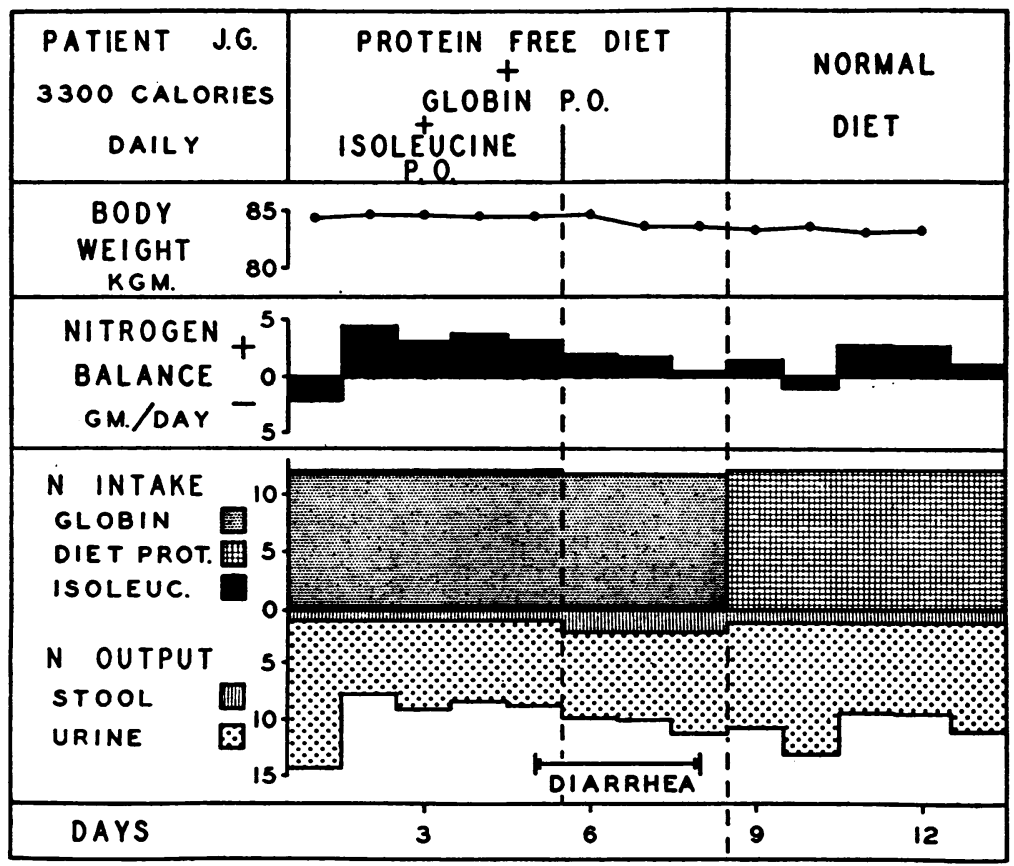

Fig. 2. Modified Human Globin Administered Orally as a Sole Source of Protein with AND without Isoleucine 


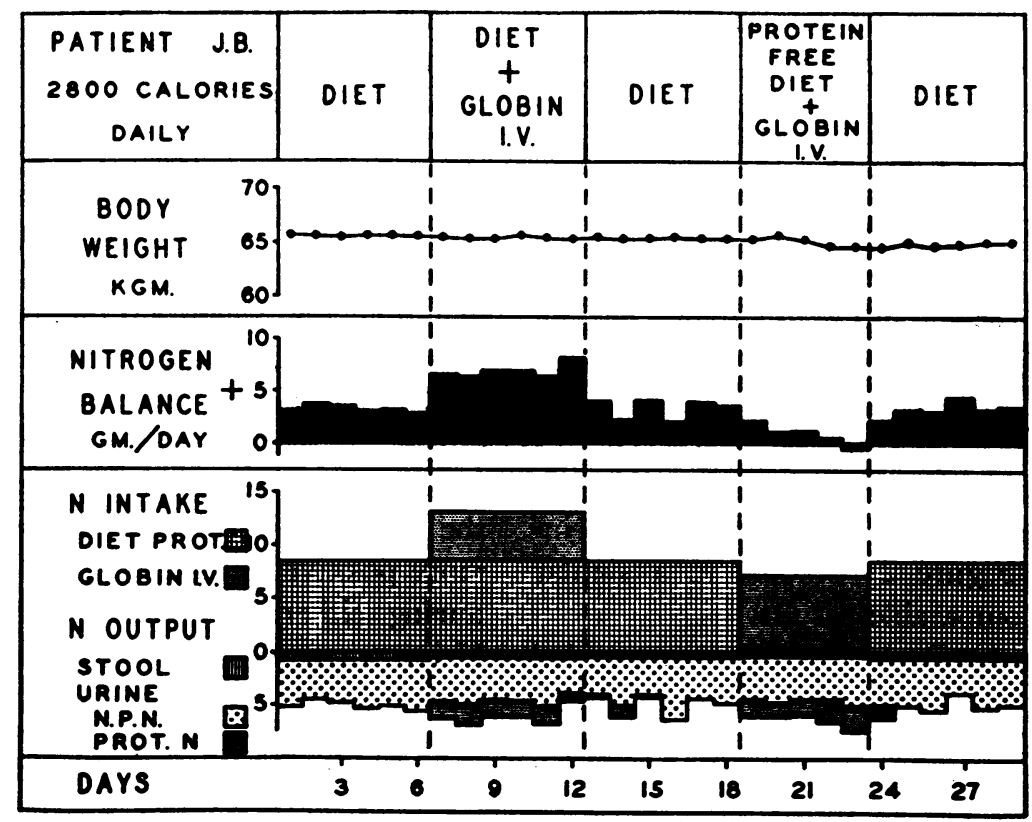

Fig. 3. Modified Human Globin Administered Intravenously as a Supplement to a Diet and Then as a Sole Source of Protein

administered intravenously. Positive nitrogen period of globin infusions. A similar study was balance again resulted, and was comparable in done in another patient, J. R., (Figure 5). The magnitude to the balance obtained during the results of this study were comparable to those ob-

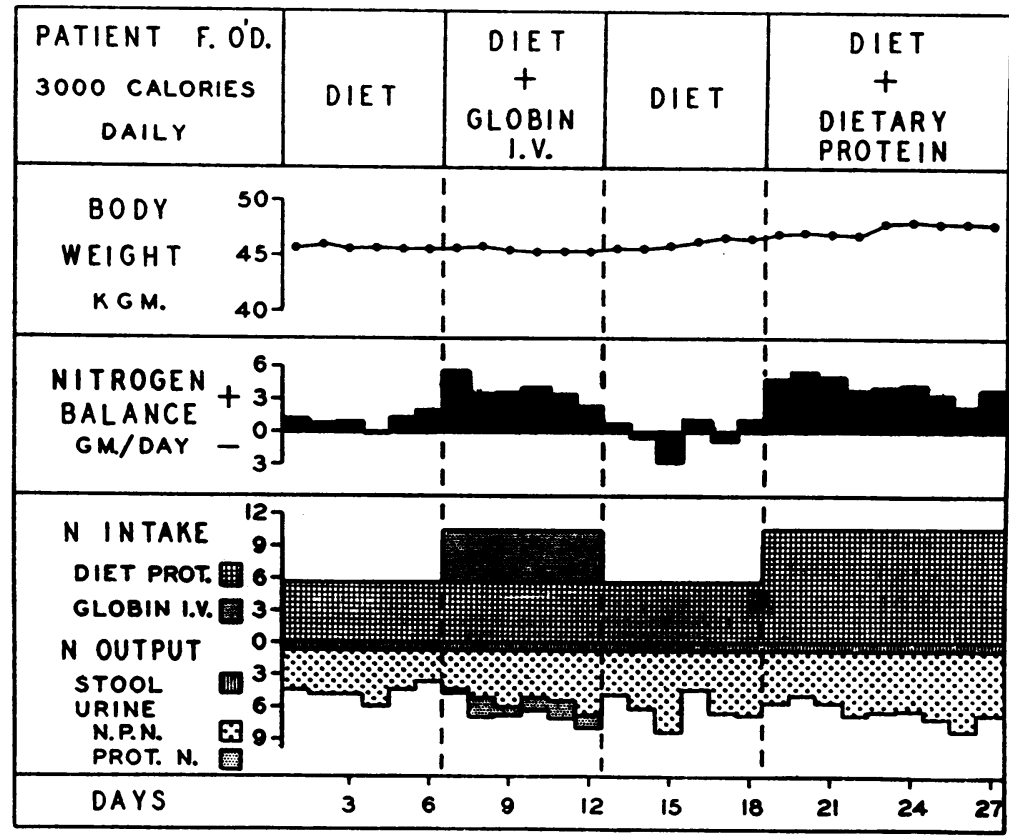

Fig. 4. Modified Human Globin Administered Intravenously as a Supplement to a Diet and Compared to an Equivalent Quantity of Dietary Protein 


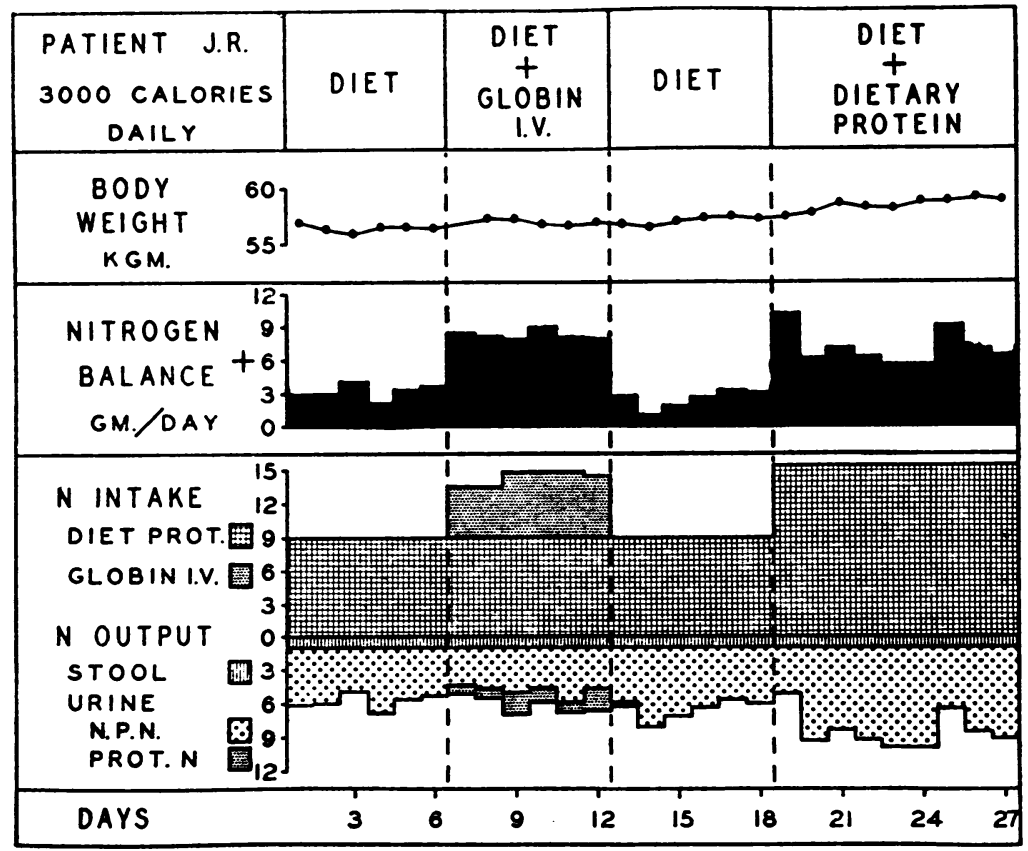

Fig. 5. Modified Human Globin Administered Intravenously as a SupPlement to a Diet and Compared to an Equivalent Quantity of Dietary Protein

served in F. O'D., intravenously administered globin again comparing favorably with an approximately equivalent amount of dietary protein.
The metabolic data of another subject, W. O., maintained on a constant diet providing $50 \mathrm{Gm}$. of dietary protein and 2,800 calories per day are

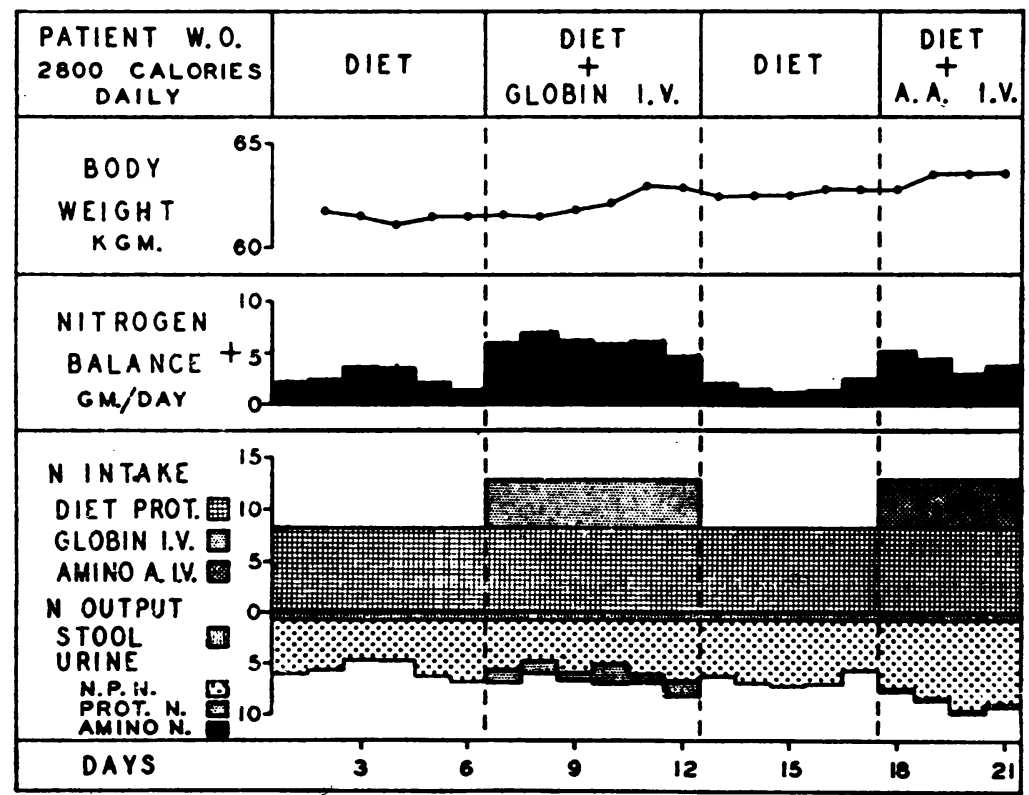

Fig. 6. Modified Human Globin Administered Intravenously as a Supplement to a Diet and Compared to an Equivalent Quantity of Amino Acids Given Intravenously 
TABLE II

Proteinuria following intravenous infusions of globin

\begin{tabular}{lccccc}
\hline \hline & $\begin{array}{c}\text { Globin } \\
\text { Patient }\end{array}$ & $\begin{array}{c}\text { Average } \\
\text { infusion } \\
\text { time } \\
\text { Hours }\end{array}$ & $\begin{array}{c}\text { Urinary } \\
\text { protein } \\
\text { Gm./day }\end{array}$ & $\begin{array}{c}\text { Per cent } \\
\text { excreted }\end{array}$ \\
\hline J.R. & 32 & 6 & 3 & 8.0 & 25.0 \\
W. O. & 32 & 6 & $2 \frac{1}{4}$ & 7.2 & 22.5 \\
F.O'D. & 32 & 6 & 2 & 7.2 & 22.5 \\
J. B. & 48 & 5 & 2 & 11.3 & 23.5 \\
J. B. & 32 & 6 & 1 1 & 9.2 & 28.8 \\
\hline
\end{tabular}

presented in Figure 6. Following a control period, $4.6 \mathrm{Gm}$. of nitrogen as globin were given intravenously for six days in addition to the basal diet. During this period of globin infusions several grams of nitrogen were retained. The urinary nitrogen excretion increased but the non-protein nitrogen excreted in the urine did not change significantly indicating that this increase was due to the excretion of protein. Following a postinfusion control period, the patient was given intravenously a solution of amino acids ${ }^{7}$ containing ample quantities of the essential amino acids. This solution furnished an equivalent amount of nitrogen, and was given in the same volume of fluid and at the same rate of infusion as the previously administered globin. Positive nitrogen balance again occurred during a four-day period of observation, but was less than that observed during globin administration. This less positive nitrogen balance could not be attributed to aminoaciduria, since only a small proportion of the infused amino acids were lost in the urine.

The increased urinary excretion of nitrogen noted in the patients during intravenous globin administration was due to proteinuria primarily. Table II indicates the extent of this loss in the patients studied, to whom 32 to $48 \mathrm{Gm}$. of globin were given intravenously daily for five to six days with average infusion times ranging from one and one half to three hours. The daily loss of protein in the urine ranged from 7.2 to $11.3 \mathrm{Gm}$. Thus, 22.5 to 28.8 per cent or approximately one-fourth of the infused globin was lost in the urine as protein. The proteinuria had no relation to the time required for the infusion. The magnitude of proteinuria following globin infusions noted in the present study is similar to that reported by Water-

7 "Solution of Amino Acids" furnished by Merck and Company, Rahway, New Jersey.
TABLE III

Proteinuria (Gm. per day) following I.V. human globin and albumin

\begin{tabular}{|c|c|c|c|c|}
\hline \multirow[b]{2}{*}{ Days } & \multicolumn{2}{|c|}{ Days of infusion } & \multicolumn{2}{|c|}{ Days after infusion } \\
\hline & $\begin{array}{l}\text { Patient } \\
\text { J. R. } \\
\text { 32 Gm. } \\
\text { globin } \\
\text { I.V. } \\
\text { daily }\end{array}$ & $\begin{array}{l}\text { Patient } \\
\text { C. J. } \\
50 \mathrm{Gm} \text {. } \\
\text { albumin } \\
\text { I.V. } \\
\text { daily }\end{array}$ & J. $R$. & C. J. \\
\hline $\begin{array}{r}1 \\
2 \\
3 \\
4 \\
5 \\
6 \\
7 \\
8 \\
9 \\
16\end{array}$ & $\begin{array}{r}5.6 \\
5.6 \\
12.5 \\
8.1 \\
5.6 \\
10.6\end{array}$ & $\begin{array}{l}0.0 \\
0.0 \\
0.0 \\
0.0 \\
0.0 \\
1.0 \\
1.0 \\
2.2 \\
5.0 \\
8.0\end{array}$ & $\begin{array}{l}2.5 \\
0.0 \\
0.0 \\
0.0 \\
0.0 \\
0.0 \\
0.0 \\
0.0 \\
0.0\end{array}$ & $\begin{array}{l}6.3 \\
7.7 \\
5.0 \\
3.5 \\
1.7 \\
0.5 \\
0.3 \\
0.0 \\
0.0\end{array}$ \\
\hline
\end{tabular}

house, Fenninger, and Keutmann (5), but greater than that observed by others $(7,16)$.

Table III contrasts modified human globin and concentrated human serum albumin with respect to the proteinuria which occurs following their intravenous administration. Patient J. R. received $32 \mathrm{Gm}$. of globin daily for six days. On the first day and on each successive day of globin administration, significant quantities of protein appeared in the urine; but proteinuria was not present during the days immediately following cessation of globin infusions. Patient C. J. received $50 \mathrm{Gm}$. of albumin intravenously daily for 16 days. Proteinuria did not occur until the sixth day of infusion and then only gradually increased. After discontinuation of albumin therapy, the proteinuria cleared gradually during the next six days. This disparity in excretion rates may be related to the difference in molecular size of the two protein preparations since the molecular weight of albumin is approximately twice that of the modified human globin preparation used.

Modified human globin was not detected in the serum 24 hours following single or multiple infusions. Moreover, in one study electrophoretic analysis $^{8}$ of the serum obtained 24 hours following the administration of $192 \mathrm{Gm}$. of globin in six days did not show the characteristic boundary of

8 The analysis was done by Dr. Peter Bernfeld, Tufts College Medical School, using veronal buffer $\mathrm{pH} 8.60$, ionic strength u 0.1 , electrical field $8.8 \mathrm{~V} . / \mathrm{cm}$. The photographs were taken after 4,800 seconds. The mobility of the globin was $4.28 \times 10^{-6} \mathrm{~cm}^{2}$ volt $^{-2}$ seconds ${ }^{-3}$. 
globin. The rapid disappearance of infused globin from the blood has been noted by others $(7,16)$. In contrast to this, following the daily administration of concentrated human serum albumin the level of albumin in the blood progressively rises and after cessation of administration there follows a slow and progressive decrease (17). The complete removal of globin from the blood even when given on consecutive days probably indicates that, apart from the fraction excreted in the urine, it is metabolized or stored in the body. The rise in plasma and urine alpha amino nitrogen which occurred following the infusion of globin (Figure 7) offers further evidence that the globin is metabolized. These increases are of such magnitude that they cannot be accounted for by the free alpha amino nitrogen content of the globin itself.
II. Clinical tolerance. Fifty-two infusions of freshly mixed 4 per cent globin in water were administered to twenty individuals in quantities ranging from 16 to 32 grams per infusion and at rates varying from 0.14 to 0.96 gram per kilogram per hour. Four subjects received 32 grams intravenously daily for six consecutive days.

There were no serious untoward reactions, although the incidence of annoying reactions was high (Table IV). The most frequent of these was flushing which occurred with most of the lots of globin used. The intensity of the erythema was proportional to the speed of the infusion and could be increased or decreased by respectively altering the infusion rate. The second most common undesirable effect was pruritis which appeared in many of the patients displaying the flush. Mild

EFFECT OF GLOBIN INFUSION ON URINARY PROTEIN, ALPHA.AMINO NITROGEN, AND VOLUME AND ON SERUM GLOBIN AND ALPHA.AMINO NITROGEN

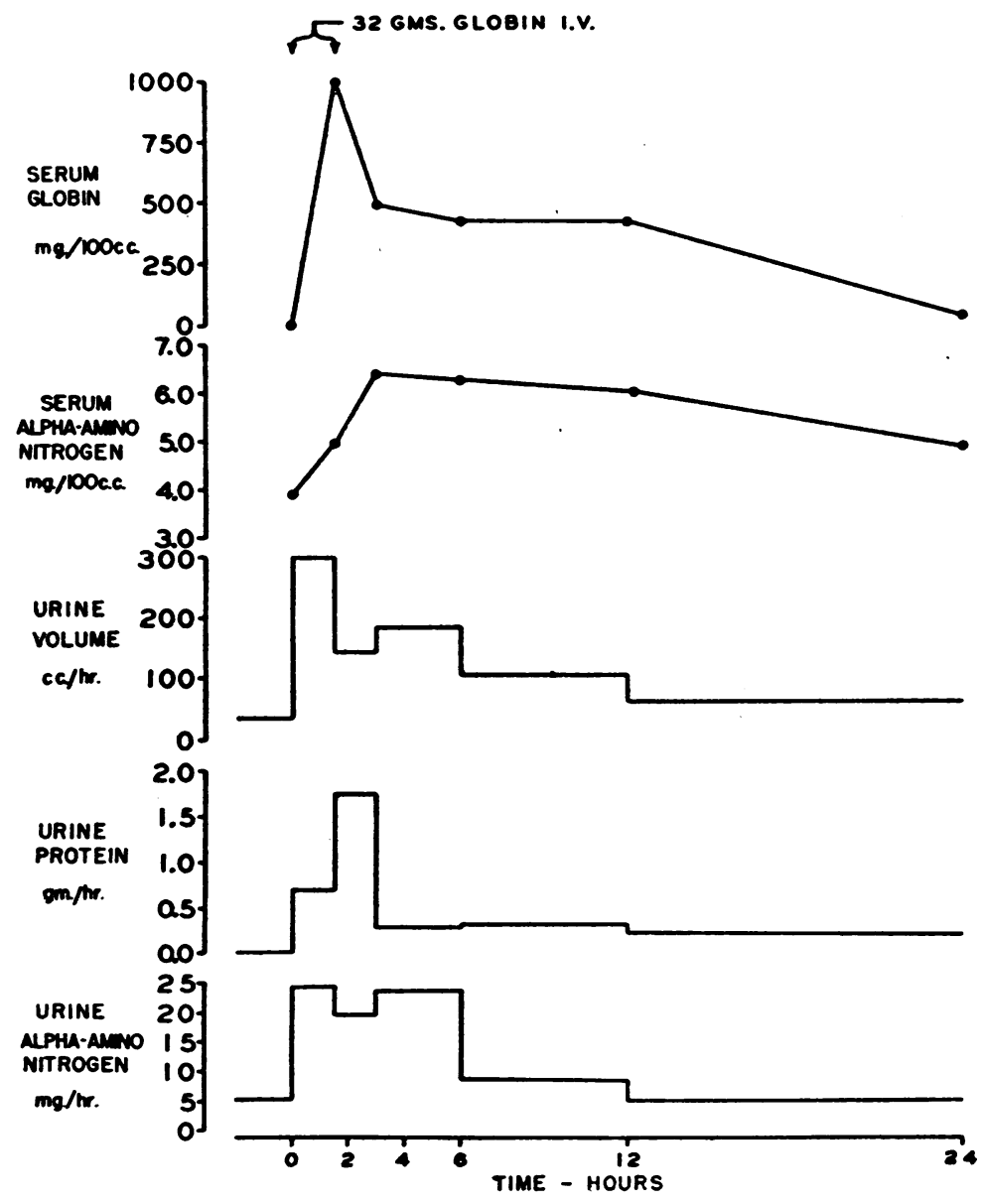

Figure 7 
TABLE IV

\begin{tabular}{|c|c|c|c|c|}
\hline Reactions & $\begin{array}{l}\text { No. } \\
\text { reactions }\end{array}$ & $\begin{array}{l}\text { No. } \\
\text { subjects }\end{array}$ & $\begin{array}{c}\text { Per cent } \\
\text { infusions }\end{array}$ & $\begin{array}{l}\text { Per cent } \\
\text { subjects }\end{array}$ \\
\hline $\begin{array}{l}\text { Flush: } \\
\text { Marked } \\
\text { Moderate } \\
\text { Mild }\end{array}$ & $\begin{array}{r}8 \\
18 \\
9\end{array}$ & 12 & 67 & 60 \\
\hline Total & 35 & & & \\
\hline $\begin{array}{l}\text { Itching } \\
\text { Chills and fever } \\
\text { Nausea } \\
\text { Anorexia } \\
\text { Vomiting } \\
\text { Local reaction }\end{array}$ & $\begin{array}{r}21 \\
6 \\
1 \\
0 \\
0 \\
0\end{array}$ & $\begin{array}{l}9 \\
6 \\
1\end{array}$ & $\begin{array}{r}40 \\
12 \\
2\end{array}$ & $\begin{array}{r}45 \\
30 \\
5\end{array}$ \\
\hline
\end{tabular}

Blood pressure, pulse, respiration : No consistent or significant changes.

* Each infusion furnished 16 or $32 \mathrm{Gm}$. of globin.

pyrogenic reactions also occurred, but were limited to four of the twelve lots of globin used. Local reactions did not occur. Blood pressure, pulse, and respiratory rates taken before and after 20 infusions in 14 subjects showed no noteworthy changes. Despite eleven infusions of a total of $432 \mathrm{Gm}$. of globin administered over the course of 17 days to one subject (J. B.) with minimal cirrhosis of the liver by biopsy, the bromsulphalein retention test and the serum bilirubin level remained normal.

Complete urinalyses were done immediately before and after globin infusions in 11 of these patients. No abnormalities developed in tests for albumin (heat and acetic acid), for reducing substances (Benedict's reagent), or in microscopic examination of the sediments. All of the postinfusion urines, however, produced a heavy precipitate with Esbach's reagent (a solution of picric and citric acids). A solution of 4 per cent globin, similarly tested, likewise gave a heavy precipitate with Esbach's reagent but no precipitate with heat and acetic acid, suggesting that the proteinuria accompanying the globin infusions resulted from the renal excretion of the infused material. These two tests for urinary protein offered a simple means of distinguishing "globinuria" from the ustual proteinuria, as the latter is precipitated by heat and acetic acid as well as by Esbach's reagent.

To investigate the possibility of in vivo hemolysis with 4 per cent globin, urine guaiac tests were made on the eleven pre- and post-infusion urines.
All pre-infusion specimens were guaiac negative, while eight of the eleven post-infusion specimens gave a positive reaction. But since the 4 per cent aqueous solution of globin itself was found to give a markedly positive guaiac (and benzidine) test, the guaiac positivity of the post-infusion urines was due presumably to the urinary excretion of the infused material. "Red urine" was not observed in any of the patients who received globin intravenously.

To determine whether or not globin interferes with the typing and cross-matching of blood, two patients were infused with 32 grams of globin in one hour. Blood samples drawn immediately after the infusion showed no rouleaux formation, and typing and cross-matching were accomplished without difficulty.

\section{COMMENT}

Solutions of protein for parenteral feeding should be free from untoward reactions, and the protein should be of good quality and readily available to the body cells. The availability of globin is indicated by its ability to maintain nitrogen balance when given as a sole source of nitrogen orally, by its approximate equivalence nutritionally to comparable quantities of nitrogen as protein by mouth or amino acids intravenously, and by the failure to find globin in the blood 24 hours after prolonged daily parenteral administration. Finally, the rapid appearance of aminoacidemia and aminoaciduria following globin infusions suggest a rapid breakdown of the globin. Human serum albumin given intravenously has a 50 per cent disappearance time of about five to ten days (17, 18). In contrast, the half-life of globin is probably several hours as indicated in the present study and studies utilizing $\mathrm{I}^{181}$ tagged globin (16). Untoward reactions following globin infusions, although frequent in occurrence, were never severe nor harmful in the studies reported here. Their incidence has been reported to have decreased with lots of globin manufactured more recently than those used in this study (6). The urinary excretion of large quantities of protein following the intravenous administration of globin gives rise to a consideration of possible renal damage. The suggestion that some of the urinary protein is not globin but serum protein (6) supports this thesis, as do occasional reports of hematuria. Further 
and more detailed studies of renal function must be done to exclude renal damage as a complication of globin administration. Post-infusion urine examinations were not abnormal in the present study and Brandt, Caccese, and Ginsberg (19) found no evidence of changes in renal function following globin administration.

Considering the high level of urinary excretion, and rapid breakdown in the body of globin as compared to albumin, one might suspect that globin would be a less effective plasma expander than albumin or plasma. Nevertheless, the duration of action of globin may be sufficient to warrant its use as a plasma volume expander in the management of emergency situations. For example, globin has been used in the treatment of postoperative shock and shock accompanying hemorrhage or burns $(2,6,7)$.

Although the data presented are too limited to justify a comparison of the nutritive adequacy of globin to solutions of amino acids or protein hydrolysates, the usefulness of parenterally administered globin may lie in its ability to furnish available protein.

\section{SUM MARY AND CONCLUSIONS}

The nutritive value of modified human globin was investigated by nitrogen balance studies in six men. The studies indicate that nitrogen balance and body weight were maintained while globin was given orally to two men for 8 and 11 days, respectively, as the sole source of protein in a calorically adequate diet. Although the quantities of globin administered orally provided less than the tentative minimum daily requirement of isoleucine as estimated by Rose (13), the oral supplementation of globin with this amino acid did not enhance the nutritive adequacy of globin as measured by nitrogen balance in two subjects. Globin given intravenously as a supplement to a constant diet resulted in increased positive nitrogen balance and retention of nitrogen of magnitude comparable to that observed during subsequent study periods during which equivalent quantities of dietary protein were ingested. The increases in urinary nitrogen excretion noted during intravenous globin administration were attributable primarily to the excretion of approximately 25 per cent of the infused material as protein.
That infused globin rapidly disappears from the blood is indicated by the prompt cessation of proteinuria after globin infusions, and the failure to detect significant quantities of globin in the serum 24 hours after its administration. The rise in plasma and urinary alpha amino nitrogen which occurred following the infusion of this protein suggest it is rapidly metabolized.

No serious untoward reactions resulted from intravenously administered modified human globin, although transient flushing, pruritus, and mild pyrogenic reactions occurred frequently.

These studies indicate that modified human globin may be useful as a source of protein for parenteral alimentation. Investigation of its adequacy as a plasma volume expander was not undertaken, but the prompt disappearance from the blood of intravenously administered globin, resulting, in part at least, from its rapid rate of metabolism and high level of urinary excretion, suggests that its usefulness for this purpose may be limited.

\section{ACKNOWLEDGMENTS}

The authors are grateful to the Misses Alice Ballou, Ellen Doyle, and Virginia Olsson for technical assistance, and to Mrs. J. Spencer Rochefort and Miss Barbara Wolfe for preparing and calculating the diets used.

\section{REFERENCES}

1. Strumia, M. M., and Sample, A. B., Modified globin. I. Method for preparation from human erythrocytes. J. Lab. \& Clin. Med., 1951, 37, 959.

2. Strumia, M. M., Chornock, F. W., Blake, A. D., and Karr, W. G., The use of a "modified globin" from human erythrocytes as a plasma substitute. Preliminary report. Am. J. M. Sc., 1945, 209, 436.

3. Strumia, M. M., Blake, A. D., Reider, H. C., and Chornock, F. W., The use of a "modified globin" from human erythrocytes in hypoproteinemias. Am. J. M. Sc., 1946, 211, 51.

4. Robscheit-Robins, F. S., Miller, L. L., Alling, E. L., and Whipple, G. H., Plasma substitutes: human and animal globin related to the production of hemoglobin and plasma protein: dog hemoglobin utilization improved by methionone but not isoleucine. J. Exper. Med., 1946, 83, 355.

5. Waterhouse, C., Fenninger, L. D., and Keutmann, $\cdot$. H., The use of modified globin as a protein supplement in normal individuals. J. Clin. Invest., 1952, 31, 670.

6. Davidson, C. S., Studies of the effects of modified human globin in man. Quart. Rev. Med., August, 1952, 9, 165. 
7. Strumia, M. M., McGraw, J. J., Jr., and Sample, A. B., Modified globin. IV. Some of the physiological properties of modified human globin. J. Lab. \& Clin. Med., 1952, 40, 211.

8. Bowes, A. deP., and Church, C. F., Food Values of Portions Commonly Used. Fifth edition. 46 pp. Phil. Child Health Soc., 1944.

9. Bridges, M. A., and Mattice, M. R., Food and Beverage Analyses. Lea \& Febiger, Philadelphia, 1942, Ed. 2.

10. Boger, W. P., and Bayne, G. M., Globin Conference sponsored by Medical Division, Sharp and Dohme, Inc., April 2, 1951, Glenolden, Pa.

11. Sample, A. B., Strumia, M. M., and Satta, V., Modified globin. III. Determination of modified globin in blood serum and in urine. J. Lab. \& Clin. Med.; 1952, 40, 206.

12. Hamilton, P. B., and Van Slyke, D. D., The gasometric determination of free amino acids in blood filtrates by the ninhydrin-carbon dioxide method. J. Biol. Chem., 1943, 150, 231.

13. Rose, W. C., Amino acid requirements of man. Federation Proc., 1949, 8, 546.

14. Stokes, J. L., Gunnes, M., Dwyer, I. M., and Caswell, M. C., Microbiological methods for the determina- tion of amino acids. II. A uniform assay for the ten essential amino acids. J. Biol. Chem., 1945, $160,35$.

15. Albanese, A. A., Studies on human blood proteins. I. The isoleucine deficiency of hemoglobin. J. Biol. Chem., 1945, 157, 613.

16. Berson, S. A., Yalow, R. S., Post, J., Wisham, L. H., Newerly, K. N., Villazon, M. J., and Vazquez, $O$. N., Distribution and fate of intravenously administered modified human globin and its effect on blood volume. Studies utilizing $I^{181}$ tagged globin. J. Clin. Invest., 1953, 32, 22.

17. Eckhardt, R. D., and Davidson, C. S., The metabolism of human serum albumin administered to man. Symposia on Nutrition. II. Plasma Proteins, pp. 275-311 by Robert Gould Research Foundation, Inc., Charles C Thomas, Springfield, 1950.

18. Sterling, $K$., The turnover rate of serum albumin in man as measured by I"12-tagged albumin. J. Clin. Invest., 1951, 30, 1228.

19. Brandt, J. L., Caccese, A., and Ginsberg, V., Effects of modified human globin in normal human subjects. Proc. Soc. Exper. Biol. \& Med., 1951, 77, 108. 